\title{
KETERKAITAN ANTARA KONDISI LINGKUNGAN DAN PERILAKU MASYARAKAT TERHADAP KEBERADAAN VEKTOR DEMAM BERDARAH DENGUE (DBD)
}

\author{
Nurul Kharomah Iin ${ }^{1 *}$, Diah Lina Yulianti ${ }^{1}$, Natalia Gega Luron ${ }^{1}$, \\ Sitti Fizraini Pomalingo ${ }^{1}$, Winda Noviana ${ }^{1}$, Nurman Hidaya ${ }^{2}$ \\ 1, Mahasiswi Program Diploma Jurusan Keperawatan, Universitas Borneo Tarakan \\ 2 Dosen Jurusan Keperawatan Universitas Borneo Tarakan \\ *Email: nurulkhaiin28@gmail.com
}

\begin{abstract}
Abstrak
Demam Berdarah Dengue (DBD) adalah salah satu penyakit yang ditularkan oleh gigitan nyamuk Aedes aegypti. Penyebaran dan tinggi rendahnya angka kesakitan demam berdarah dipengaruhi oleh beberapa faktor diantaranya dikarenakan tinggi rendahnya populasi vektor. Dalam proses pencarian literatur digunakan beberapa database seperti Neliti, Google scholar dan sciencedirect. Kata kunci yang dimasukkan adalah kata kunci yang relevan dengan materi yaitu "Faktor yang Mempengaruhi Demam Berdarah Dengue" dan "Dengue Hemorrhagic Fever". Dari berbagai temuan literatur akhirnya penulis memilih 19 artikel penelitian yang digabungkan dan dianggap relevan dengan topik pembahasan. Dari berbagai macam artikel penelitian disimpulkan bahwa adanya keterkaitan antara kondisi lingkungan dan perilaku masyarakat terhadap vektor demam berdarah dengue yang sangat berperan terhadap penularan ataupun terjadinya kejadian Demam Berdarah Dengue.
\end{abstract}

Kata Kunci : Faktor Lingkungan, Keberadaan Vektor DBD, Perilaku Masyarakat

\begin{abstract}
Relationship Between Environmental Conditions And Community Behavior Towards Vector Existence Dengue Hemorrhagic Fever (DHF). Dengue Hemorrhagic Fever $(D H F)$ is one of the diseases transmitted by Aedes aegypti mosquito bites. The spread and high and low rates of dengue fever are influenced by several factors including the high and low vector population. In the process of searching literature used several databases such as Neliti, Google Scholar, and ScienceDirect. The keywords entered are keywords that are relevant to the material namely "Factors Affecting Dengue Hemorrhagic Fever" and "Dengue Hemorrhagic Fever". From various literature findings, the writer finally chose 19 research articles which were combined and considered relevant to the topic of discussion. From various research articles, it can be concluded that there is a relationship between environmental conditions and people's behavior towards dengue vectors which is very influential in the transmission or occurrence of dengue fever.
\end{abstract}

Keyword: Environmental Factor, The Existence of DHF Vector, Public Behavior 
Iin, dkk. Keterkaitan antara Kondisi Lingkungan dan Perilaku Masyarakat Terhadap Keberadaan

Vektor Demam Berdarah Dengue (DBD). Journal of Borneo Holistic Health, Vol. 3 No. 2 Desember

2020 hal 75-85

\section{Pendahuluan}

Demam berdarah adalah penyakit yang disebabkan oleh virus yang disebabkan oleh infeksi arthropoda dengan salah satu dari 4 serotipe virus demam berdarah. Virus dengue adalah virus RNA yang memiliki genus Flavivirus. Dengue adalah masalah global yang penting dalam perawatan kesehatan. Setidaknya 3,6 miliar orang yang hidup di lebih dari 125 negara tropis dan subtropis berisiko terkena infeksi dengue. Di dunia internasional, hingga 22.000 kematian dikaitkan dengan demam berdarah per tahun (Khurram, et al, 2014). Sekitar 2500 juta orang dilaporkan tinggal di daerah dengan risiko yang diperkirakan lebih besar dari 50\% untuk penularan demam berdarah, salah satu penyakit yang ditularkan melalui vektor yang paling luas di dunia (Wu, et.al, 2009).

Sekitar 390 juta kasus terjadi setiap tahun. Presentasi klinis dari demam berdarah bervariasi dari infeksi tanpa gejala hingga infeksi yang mengancam jiwa. Kebanyakan gejala dengue sembuh sendiri, dan timbul dengan demam tinggi, sakit kepala, mialgia, artralgia dan ruam. Dengue dapat berkembang menjadi dengue yang parah, ditandai dengan kebocoran plasma yang parah, perdarahan hebat atau kegagalan organ (Chen, et.al. 2019). Dengue telah dilaporkan terjadi di hampir 70 negara, dengan sekitar lima juta kasus dilaporkan antara 2000 dan 2007 (Fontal, et.al. 2011).

Demam Berdarah Dengue (DBD) ini ditularkan oleh gigitan nyamuk Aedes aegypti, yang paling umum mempengaruhi manusia. Demam berdarah telah menjadi masalah nasional bahkan internasional. Sampai sekarang penyakit DBD belum ditemukan obat maupun vaksinnya, sehingga satu-satunya cara untuk mencegah terjadinya penyakit ini dengan memutuskan rantai penularan yaitu dengan pengendalian vektor (Setiyawan, 2019). Di Indonesia sendiri, penyakit demam berdarah dengue masih menjadi masalah kesehatan yang utama.

Penyakit DBD di Indonesia pertama kali terjadi di Surabaya pada tahun 1968. Pada tahun 1994 kasus DBD menyebar ke 27 provinsi di Indonesia. Tahun 1968 jumlah kasus DBD sebanyak 53 orang (Incidence Rate (IR) 0.05/100.000 penduduk) meninggal 24 orang $(42,8 \%)$. Sejak saat itu, penyakit ini menyebar luas ke seluruh Indonesia. Pada tahun 2005 jumlah kasus sebanyak 95.279 (IR: 43,31/100.000 penduduk) dengan 1.298 kematian (Case Fatality Rate (CFR): 1,36\%), tahun 2006 jumlah kasus sebanyak 114.656 (IR: 52,48/100.000 penduduk) dengan 1.196 kematian (Case Fatality Rate: 1,04\%) sampai dengan bulan November 2007, 
kasus telah mencapai 124.811 (IR: 57,52/100.000 penduduk) dengan 1.277 kematian (CFR: 1,02\%) (Prasetyani, 2015).

Peningkatan dan penyebaran kasus demam berdarah dengue (DBD) kemungkinan disebabkan oleh beberapa faktor diantaranya seperti kondisi lingkungan dan sikap masyarakat. Sofia (2014) juga menyatakan bahwa kasus DBD kemungkinan disebabkan oleh mobilitas penduduk yang tinggi, perkembangan wilayah perkotaan, perubahan iklim, perubahan kepadatan dan distribusi penduduk serta faktor epidemiologi lainnya. Kondisi ini diperburuk dengan pemahaman masyarakat yang kurang tentang DBD dan juga partisipasi masyarakat yang rendah. Selain itu, penyebaran dan tinggi rendahnya angka kesakitan demam berdarah dengue juga dipengaruhi oleh populasi vektor demam berdarah dengue. Sehingga populasi vektor memegang peranan penting terhadap meningkatnya populasi aedes aegypti sebagai penular penyakit demam berdarah.

Oleh karena itu, tujuan penulisan ini adalah untuk membuktikan bahwa adanya keterkaitan antara kondisi lingkungan dengan perilaku masyarakat terhadap keberadaan vektor demam berdarah dengue.

\section{Metode}

Metode yang digunakan pada artikel review ini adalah penelusuran terhadap data-data penelitian yang berkaitan dengan penyakit DBD. Sumber pustaka yang digunakan dalam artikel review ini berasal dari jurnal nasional, jurnal internasional dan website. Pada proses pencarian literatur, penulis menggunakan 3 data base elektronik yaitu Neliti, Google scholar dan Sciencedirect. Kata kunci yang dimasukkan adalah kata kunci yang relevan dengan materi yaitu "Faktor yang Mempengaruhi Demam Berdarah Dengue" dan "Dengue Hemorrhagic Fever". Artikel penelitian yang didapat dari kata kunci ini adalah sebanyak 43 artikel penelitian dan yang relevan dengan penelitian tentang kondisi lingkungan dan perilaku masyarakat terhadap vektor DBD sebanyak 19 artikel penelitian. Dari berbagai temuan literatur akhirnya penulis memilih 19 artikel penelitian tersebut digabungkan dan dianggap relevan dengan topik pembahasan yang akan disimpulkan dalam Literature Review.

Studi kelayakan dilakukan dengan menggunakan kriteria inklusi dan eksklusi. Kriteria inklusi yang ditetapkan penelitian menggunakan data primer, membatasi terbitan dari tahun 2007 sampai dengan 2020, berbahasa Indonesia dan Inggris, 
artikel dapat diakses secara terbuka (open access), telah melalui tahapan peer review, merupakan artikel full text dan membahas tentang kondisi lingkungan dan perilaku masyarakat terhadap vektor DBD. Kriteria eksklusi pada penelusuran ini adalah yang tidak termasuk dalam tujuan literature review atau tidak berhubungan dengan tujuan literature review.

\section{Hasil dan pembahasan}

Penyakit demam berdarah dengue (DBD) merupakan salah satu masalah kesehatan masyarakat yang penting di Indonesia dan sering menimbulkan suatu kejadian luar biasa dengan kematian yang besar. Adapun beberapa faktor yang mempengaruhi terjadinya kejadian demam berdarah dengue yaitu faktor lingkungan dan perilaku masyarakat. Diantaranya: faktor kepadatan penduduk, mobilitas penduduk, keberadaan kontainer, keberadaan pot tanaman hias, sikap, tindakan pembersihan sarang nyamuk, dan kebiasaan menggantung pakaian.

\section{Kepadatan Penduduk}

Perubahan jumlah populasi setiap waktu merupakan salah satu penanda terjadinya pertumbuhan populasi yang dipengaruhi oleh jumlah kelahiran, kematian dan migrasi. Jumlah populasi yang meningkat akan mengakibatkan perubahan kepadatan penduduk. Kepadatan penduduk merupakan indikator daripada tekanan penduduk di suatu daerah. Kepadatan di suatu daerah dibandingkan antara banyaknya penduduk per kilometer persegi dengan luas tanah yang ditempati (Apriyandika, 2013).

Faktor kependudukan seperti kepadatan penduduk akan mempengaruhi proses penularan atau pemindahan suatu penyakit dari satu orang ke orang lainnya. Begitu Pula yang terjadi pada kasus DBD, dimana kepadatan penduduk yang tinggi akan mempermudah terjadinya transmisi virus dengue oleh vektor nyamuk Aedes aegypti, sehingga jumlah insiden kasus DBD di daerah yang berpenduduk padat tersebut akan meningkat (Soedarto, 2012). Wilayah dengan kepadatan penduduk yang tinggi memberikan peluang besar nyamuk Aedes aegypti yang terdapat virus dengue di dalam tubuhnya dalam penularan DBD. Semakin padat suatu wilayah, maka potensi penularan penyakit semakin besar. Jumlah penderita dan luas daerah penyebarannya semakin bertambah seiring dengan kepadatan penduduk (Kemenkes RI, 2012).

Menurut Apriyandika kepadatan penduduk dapat mempengaruhi jumlah kejadian DBD. Jumlah individu yang besar berada di suatu wilayah tertentu akan memudahkan penyebaran penyakit DBD, karena akan memudahkan dan 
mempercepat transmisi virus dengue dari vektor. Daerah yang padat penduduk cenderung memiliki higienitas lingkungan yang kurang baik, dan sangat bergantung pada perilaku masyarakat. Keadaan lingkungan yang kurang baik dapat mendukung terhadap perkembangbiakan vektor.

Jumlah individu yang besar di suatu wilayah tertentu akan memudahkan penyebaran penyakit DBD, karena akan mempermudah dan mempercepat transmisi virus Dengue dari vektor. Dan semakin padat penduduk maka akan menyebabkan kepadatan hunian. kepadatan penghuni adalah perbandingan jumlah penghuni dengan luas rumah dimana berdasarkan standar kesehatan adalah $10 \mathrm{~m}^{2}$ per penghuni, semakin luas lantai rumah maka semakin tinggi pula kelayakan hunian sebuah rumah (Agustina, 2017).

\section{Mobilitas Penduduk}

Mobilitas penduduk adalah suatu gerak penduduk yang dilakukan oleh seseorang, dari satu tempat ke tempat yang lain dalam jangka waktu tertentu. Mobilitas penduduk adalah gerakan penduduk yang melewati batas wilayah, dalam periode waktu tertentu. Batas wilayah tersebut umumnya digunakan batas administrasi seperti batas provinsi, kabupaten, kecamatan, kelurahan atau desa. Mobilitas penduduk yang tinggi umumnya terjadi di daerah perkotaan yang dilengkapi dengan sarana transportasi dan informasi yang maju. Hal ini terjadi karena dipengaruhi oleh profesi dan aktivitas penduduk (Dari, et al, 2020).

Mobilitas penduduk yang tinggi dan didukung oleh transportasi yang baik memudahkan terjadinya penyebaran penyakit, baik yang terbawa kendaraan maupun penduduk yang telah terinfeksi virus yang ditularkan nyamuk Aedes aegypti. Transportasi yang baik antar daerah semakin memudahkan penyebaran penyakit DBD (Dari, et al, 2020). Mobilitas penduduk memudahkan penularan dari satu tempat ke tempat lainnya dan biasanya penyakit menjalar dimulai dari suatu pusat sumber penularan kemudian mengikuti lalu lintas penduduk. Makin ramai lalu lintas itu, makin besar kemungkinan penyebaran (Sunaryo, 2014).

\section{Keberadaan Kontainer}

Bahan kontainer sebagai tempat perkembangbiakan jentik Aedes aegypti pada umumnya terbuat dari keramik, plastik, logam, karet dan tanah. Bahan kontainer dari semen merupakan yang paling banyak ditemukan jentik Aedes aegypti selain semen baban yang dominan keramik dan plastic (Widjaja, 2011). 
Jumlah larva Aedes aegypti di dalam tempat berkembang biak dipengaruhi oleh kasar halusnya dinding kontainer, warna kontainer dan kemampuan kontainer menyerap air. Pada kontainer yang kasar, gelap dan mudah menyerap air, jumlah telur yang diletakkan lebih banyak sehingga larva yang terbentuk juga lebih banyak. Jumlah larva Aedes aegypti juga dipengaruhi oleh ukuran container dan jumlah air yang terdapat di dalamnya. Tempat penampungan air yang besar dan banyak berisi air lebih banyak mengandung larva bila dibandingkan dengan kontainer yang kecil dan jumlah airnya sedikit (Widjaja, 2011).

Kontainer yang terbuka dan terletak di dalam rumah menunjukan hubungan secara signifikan dengan terjadi DBD hal ini disebabkan karena memungkinkan sebagai tempat perkembangbiakan jentik Aedes aegypti. Penggunaan penutup container yang baik, dapat mencegah berkembarebiaknya nyamuk Aedes aegypti, sedangkan banyaknya jenis kontainer ditemukan sebagai tempat berkembangnya nyamuk Aedes aegypti tergantung pada kebiasaan masyarakat setempat menggunakan wadah sebagai tempat penampungan air untuk kebutuhan seharihari (Widjaja, 2011).

\section{Keberadaan Pot Tanaman Hias}

Ada keterkaitan antara keberadaan pot tanaman hias dengan keberadaan vektor DBD. Hal ini sesuai dengan pendapat Masruroh, et al, (2016) lingkungan biologik yang mendukung perkembangbiakkan nyamuk penular penyakit DBD adalah adanya tanaman hias yang berisi air dan tanaman pekarangan/sekitar rumah di samping dapat menampung kelembaban dan pencahayaan di dalam rumah, sehingga menjadi tempat yang disenangi oleh nyamuk Aedes aegypti untuk istirahat.

\section{Sikap}

Sikap adalah respons tertutup seseorang terhadap suatu stimulus atau objek, baik yang bersifat intern maupun ekstern sehingga manifestasinya tidak dapat langsung dilihat, tetapi hanya dapat ditafsirkan terlebih dahulu dari perilaku yang tertutup tersebut. Sikap secara realitas menunjukkan adanya kesesuaian respons stimulus tertentu (Aryati, 2014).

Sikap secara nyata menunjukkan korelasi adanya kesesuaian reaksi terhadap stimulus tertentu yang dalam kehidupan sehari-hari merupakan reaksi yang bersifat emosional terhadap stimulus sosial yang dapat diukur dalam bentuk baik dan buruk atau positif dan negatif. Sikap seseorang adalah komponen yang sangat penting dalam perilaku kesehatannya yang 
kemudian diasumsikan bahwa ada hubungan langsung antara sikap dan perilaku seseorang (Febryana, et al, 2010).

Sikap masyarakat terhadap vektor DBD memiliki keterkaitan, yaitu semakin masyarakat bersikap tidak serius dan tidak berhati-hati terhadap penularan penyakit DBD akan semakin bertambah risiko terjadinya penularan penyakit DBD. Hal ini sesuai dengan pendapat Lontoh et al, (2016) salah satu faktor masih tingginya kasus demam berdarah ini adalah kurangnya pengetahuan dan sikap telah terkondisikan masyarakat sehingga berdampak pada tindakan masyarakat dalam pencegahan DBD.

\section{Tindakan Pembersihan Sarang Nyamuk}

Ada keterkaitan antara tindakan pembersihan sarang nyamuk dengan vektor DBD. Anwar \& Adi (2015) dalam penelitiannya yang berjudul hubungan lingkungan fisik dan tindakan pemberantasan sarang nyamuk dengan penyakit DBD menunjukkan bahwa ada hubungan pemberantasan sarang nyamuk dengan penyakit DBD.

Sementara penelitian Aryati, Sali, Aryasih (2014) yang berjudul hubungan pengetahuan, sikap dan tindakan masyarakat dengan kejadian DBD menunjukkan dari 45 responden yang diteliti, sebagian besar responden menyatakan telah melakukan tindakan pemberantasan sarang nyamuk DBD terkhusus pada tindakan 3M (Menguras, Menutup, Mengubur), menjaga kebersihan lingkungan, gotong royong, melakukan tindakan dengan mengubur ke dalam tanah, membakar sampah, dan ada juga yang menyatakan dijual ke pemulung. Tetapi ketika diamati secara langsung tindakan yang dilakukan sehari-hari tidak sesuai dengan apa yang mereka katakan. Maka dapat disimpulkan bahwa tindakan yang kurang baik menyebabkan adanya kejadian DBD.

\section{Kebiasaan Menggantung Pakaian}

Ada keterkaitan antara kebiasaan menggantung pakaian dengan keberadaan vektor DBD. Hal ini sesuai dengan hasil penelitian Mahardika (2009) yaitu terdapat hubungan antara menggantung pakaian bekas pakai dengan kejadian DBD. Adapun nyamuk Aedes aegypti lebih menyukai beristirahat tempat yang gelap, lembab, seperti menggantung pakaian. ketidaksesuaian hasil penelitian ini dengan penelitian yang telah ada dapat dikarenakan faktor-faktor lain yang turut menentukan diantaranya walaupun pakaian bergelantungan tetapi adanya pemakaian obat nyamuk menjadikan populasi nyamuk menjadi sedikit. 
Kebiasaan menggantung pakaian, mempunyai mempunyai resiko 6,29 kali lebih besar untuk terkena DBD dibandingkan dengan mereka yang tidak biasa menggantung pakaian (Jasrida, 2012).

Menurut Teguh Widyanto (2007) keberadaan nyamuk untuk hinggap istirahat selama menunggu waktu bertelur dan tempat tersebut gelap, lembab dan sedikit angin, dan nyamuk tersebut biasa hinggap dan menempel dipakaian di dalam rumah. Pakaian merupakan kebutuhan sandang bagi setiap manusia yang keberadaannya tidak pernah lepas dari kehidupan manusia. Namun, penanganan pakaian setelah digunakan seringkali diabaikan. Seperti halnya kebiasaan menggantung pakaian dapat menyebabkan jumlah nyamuk di dalam rumah bertambah karena seringkali nyamuk lebih senang hinggap pada pakaian yang menggantung (Dinata, 2011).

\section{Referensi}

Agustina, R. M., Nur, E. W., Retno, M. (2017). Hubungan Kepadatan Hunian dengan Kejadian Demam Berdarah Dengue di Semarang. Retrieved from: http://ejournal3.undip.ac.id/index.ph p/jkm. Diakses pada 26 Juli 2020. Pukul 20:50 WITA

Anwar, A., \& Adi. (2015). Hubungan lingkungan fisik dan tindakan PSN

\section{Kesimpulan}

Dari berbagai artikel penelitian yang dalam pembahasan maka dapat disimpulkan bahwa faktor lingkungan berupa kepadatan penduduk, mobilitas penduduk, keberadaan kontainer dan keberadaan pot tanaman hias menjadi tempat perindukan nyamuk Aedes aegypti sebagai vektor penyakit Demam Berdarah Dengue. Selain itu, faktor perilaku masyarakat juga memiliki keterkaitan dengan keberadaan vektor penyakit Demam Berdarah Dengue yaitu, sikap masyarakat, tindakan pembersihan sarang nyamuk, dan kebiasaan menggantung pakaian. Jadi, adanya keterkaitan antara kondisi lingkungan dan perilaku masyarakat terhadap vektor demam berdarah dengue yang sangat berperan terhadap penularan ataupun terjadinya kejadian Demam Berdarah Dengue.

dengan penyakit DBD di Wilayah Buffer kantor Kesehatan Pelabuhan Kelas II Samarinda. Jurnal Ilmiah Manuntung, 23.

Apriyandika. (2013). Hubungan Kepadatan Penduduk Dengan Kejadian Demam Berdarah Dengue Di Kota Bandung (Skripsi). Bandung: Universitas Islam Bandung. 
Aryati, I. C., Sali, I. W., \& Aryasih, I. A. (2014). Hubungan pengetahuan sikap dan tindakan masyarakat dengan kejadian DBD di Kelurahan Baler Bale Agung Kecamatan Negara tahun 2012. Jurnal Kesehatan Lingkungan, $4,122$.

Chen, Hung-Jui., Hung-Jen Tang., ChihChiang Chien. (2019). Warning signs and severe dengue in end-stage renal disease dialysis patients. Journal of Microbiology, Immunology and Infection, https://doi.org/10.1016/j.jmii.2019.0 8.005. Diakses pada 7 Desember 2020. Pukul 08:59 WITA

Dari, S., Andi, N., Ayu., D.P.R. (2020) Profile of Occupancy Density and Population Mobility to the Prevalence Dengue Hemorrhagic Fever in the Working Areas of Health Center Temple City of Parepare. Retrieved from:http://jurnal.umpar.ac.id/index. php/makes. Diakses pada 26 Juli 2020. Pukul 23:48 WITA

Dinata, Arda., Pandji Wibawa Dhewantara. (2011). Karakteristik Lingkungan Fisik, Biologi, dan Sosial di Daerah Endemis DBD Kota Banjar Tahun 2011. Jurnal Ekologi Kesehatan Vol.
11 No 4, Desember $2012: 315$ - 326.

Ciamis : Loka Litbang P2B2 Badan Penelitian dan Pengembangan Kesehatan Kementerian Kesehatan RI. Retrieved from: http://ejournal.litbang.kemkes.go.id/i ndex.php/jek/article/view/3835.

Diakses pada 19 Juli 2020. Pukul 11:25 WITA

Febryana, E., Apriyanti, H., Pradysta, M. K., Anindyajati, G., Karunia, A. (2010). Perbandingan pengetahuan, sikap dan perilaku mengenai demam berdarah antara Kelurahan Sosromenduran dan Pringgokusuman, Kecamatan Gedongtengen, Kodia Yogyakarta.

Gonzalez-Fontal, G.R., Andres Felipe Henao-Martinez. (2011). Dengue hemorrhagic fever complicated by pancreatitis. The Brazilian Journal of Infectious Diseases Volume 15, Issue 5September-October 2011Pages 490-492.

Jasrida yunita, dkk. (2012). Pengaruh Perilaku Masyarakat Dan Kondisi Lingkungan Terhadap Kejadian Demam Berdarah Dengue (DBD), Jurnal Kesehatan Komunitas, Vol. 1 No. 4 Mei 2012: $193-198$ 
Iin, dkk. Keterkaitan antara Kondisi Lingkungan dan Perilaku Masyarakat Terhadap Keberadaan Vektor Demam Berdarah Dengue (DBD). Journal of Borneo Holistic Health, Vol. 3 No. 2 Desember 2020 hal 75-85

Lontoh, R. Y., A. J. M. Rattu., Wulan., P. J. Kaunang. (2016). Hubungan Antara Pengetahuan Dan Sikap Dengan Tindakan Pencegahan Demam Berdarah Dengue (DBD) Di Kelurahan Malalayang 2 Lingkungan. Pharmacon Jurnal Ilmiah Farmasi Unsrat Vol. 5 No. 1 Februari 2016 ISSN $2302-2493$.

Kementerian Kesehatan RI. (2012). Profil Kesehatan Indonesia Tahun 2011. Jakarta.

Khurram, M., Wajeeha, T., Syed Jawad, U.H., Shamail, M., Hamama, T.B., Muhammad, U. (2014). Dengue hemorrhagic fever: Comparison of patients with primary and secondary infections. Journal of Infection and Public HealthVolume 7, Issue 6 November-December 2014, Pages 489-495. Retrieved from: https://www.sciencedirect.com/scien ce/article/pii/S1876034114000781

Masruroh, L., Nur, E.W., Resa, A. D. (2016). Hubungan Faktor Lingkungan dan Praktik Pemberantasan Sarang Nyamuk (PSN) dengan Kejadian Demam Berdarah Dengue (DBD) di Kecamatan Ngawi. Jurnal Kesehatan Masyarakat (E-Journal)
Volume 4, Nomor 4, Oktober 2016 (Issn: 2356-3346) Retrieved from :http://EjournalS1.Undip.Ac.Id/Index.Php/Jkm. Diakses pada 26 Juli 08:45 WITA Mahardika, Wahyu. (2009). Hubungan Antara Perilaku Kesehatan Dengan Kejadian Demam Berdarah (DBD) Di Wilayah Kerja Puskesmas Cepiring Kecamatan Cepiring Kabupaten Kendal Tahun 2009. Semarang: Universitas Negeri Semarang.

Pei-Chih Wu., Jinn-Guey Lay., How-Ran Guo., Chuan-Yao Lin., Huey-Jen Su. (2009). Higher Temperature And Urbanization Affect The Spatial Patterns of Dengue Fever Transmission In Subtropical Taiwan. Science of The Total EnvironmentVolume 407, Issue 715 March 2009Pages 2224-2233. Retrieved from: https://www.sciencedirect.com/scien ce/article/pii/S0048969708011509

Prasetyani, R.D. (2015). Faktor-Faktor yang Berhubungan dengan Kejadian Demam Berdarah Dengue. Retrieved from:

https://juke.kedokteran.unila.ac.id/in dex.php/majority/article/view/1449/1 
284. Diakses pada 24 Juli 2020. Pukul 23:35 WITA

Setiyawan, H., Asih, S. L., Elly, Nur. A., Annisa, M., Elly, D., Evi, B. U. (2019). Penyuluhan demam berdarah dengue (DBD) dan tanaman pengusir nyamuk di Desa Modalan, Banguntapan. Jurnal Pemberdayaan: Publikasi Hasil Pengabdian kepada Masyarakat Vol. 3, No. 2, Agustus 2019, Hal. 241-244. Retrieved from : https://doi.org/10.12928/jp.v3i2.849. Diakses pada 19 Juli 2020. Pukul 21.00 WITA

Sofia, Suhartono, Nur Endah Wahyuningsih. (2014). Hubungan Kondisi Lingkungan Rumah dan Perilaku Keluarga dengan kejadian Demam Berdarah Dengue Di Kabupaten Aceh Besar.

Soedarto. (2012). Demam Berdarah Dengue "Dengue Hemorrhagic Fever”. Jakarta: CV Sagung Seto.

Sunaryo., Ikawati, .B., Widiastuti, D. (2014). Status Resistensi Vektor Demam Berdarah Dengue (Aedes aegypti) terhadap Malathion 0,8\% dan Permethrin 0,25\% di Provinsi Jawa Tengah. Ekologi Kesehatan. 2014;13(2).
Widiyanto, Teguh. (2007). Kajian Manajemen Lingkungan Terhadap Kejadian

Demam Berdarah Dengue (DBD) Di Kota Purwokerto Jawa Tengah. [Thesis]. Semarang: Program Pasca Sarjana Universitas Diponegoro Semarang.

Widjaja, J. (2011). Keberadaan Kontainer Sebagai Faktor Risiko Penularan Demam Berdarah Dengue Di Kota Palu Sulawesi Tengah. Aspirator $3(2) ; 82-88$

Yunita, J., Mitra, M., \& Susmaneli, H. (2012). Pengaruh Perilaku Masyarakat dan Kondisi Lingkungan Terhadap Kejadian Demam Berdarah Dengue. Jurnal Kesehatan Komunitas, 1(4), 193-198. No. 4 Mei 2012: $193-198$ 